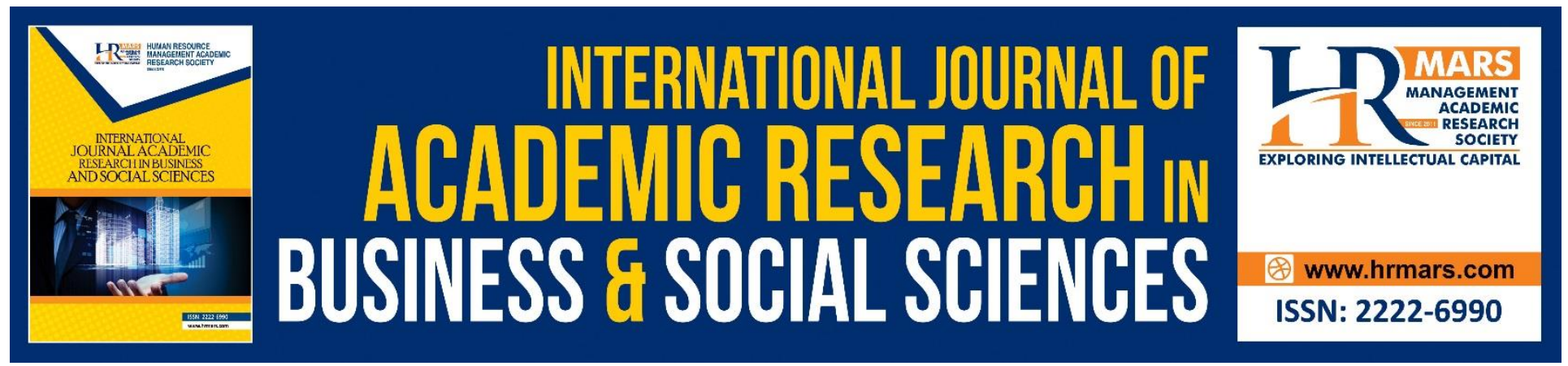

\title{
The Unique Motivational Factors Affecting Teachers Performance Among Senior High Schools in Kumasi Metropolis
}

Frank Osei Danquah, Bright Korankye Asiamah, Martinson Ankrah Twumasi

To Link this Article: http://dx.doi.org/10.6007/IJARBSS/v9-i2/5556

DOI: $\quad 10.6007 /$ IJARBSS/v9-i2/5556

Received: 17 Jan 2019, Revised: 28 Feb 2019, Accepted: 11 March 2019

Published Online: 13 March 2019

In-Text Citation: (Danquah, Asiamah, \& Twumasi, 2019)

To Cite this Article: Danquah, F. O., Asiamah, B. K., \& Twumasi, M. A. (2019). The Unique Motivational Factors Affecting Teachers Performance Among Senior High Schools in Kumasi Metropolis. International Journal of Academic Research in Business and Socal Sciences, 9(2), 414-432.

Copyright: (c) 2019 The Author(s)

Published by Human Resource Management Academic Research Society (www.hrmars.com)

This article is published under the Creative Commons Attribution (CC BY 4.0) license. Anyone may reproduce, distribute, translate and create derivative works of this article (for both commercial and non-commercial purposes), subject to full attribution to the original publication and authors. The full terms of this license may be seen

at: http://creativecommons.org/licences/by/4.0/legalcode

Vol. 9, No. 2, 2019, Pg. 414 - 432

http://hrmars.com/index.php/pages/detail/IJARBSS

JOURNAL HOMEPAGE

Full Terms \& Conditions of access and use can be found at http://hrmars.com/index.php/pages/detail/publication-ethics 


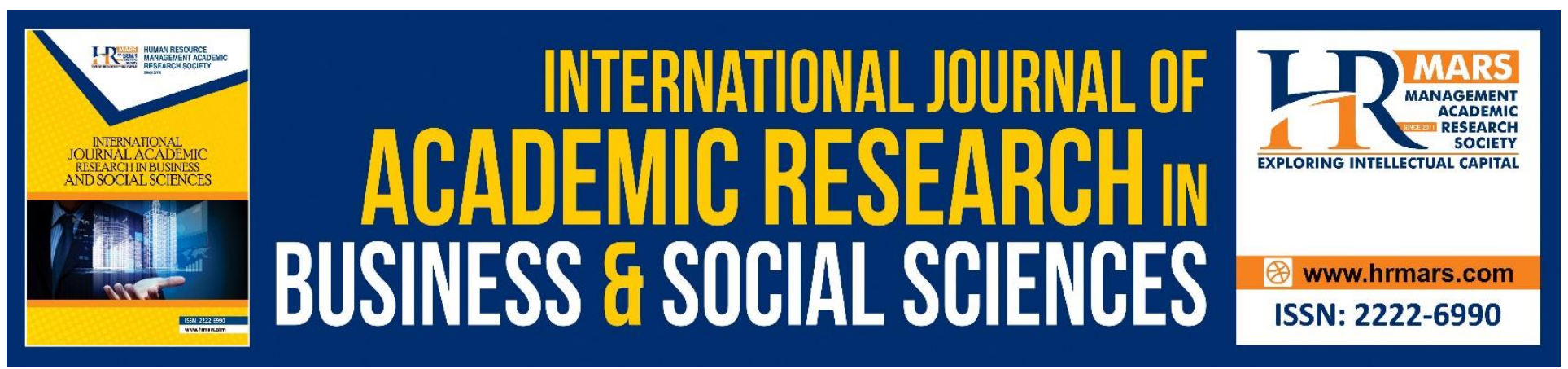

\title{
The Unique Motivational Factors Affecting Teachers Performance Among Senior High Schools in Kumasi Metropolis
}

\author{
Frank Osei Danquah ${ }^{1 *}$ Bright Korankye Asiamah² Martinson \\ Ankrah Twumasi ${ }^{1}$ \\ ${ }^{1}$ College of Economics and Management, Sichuan Agricultural University, Chengdu 611130, China \\ ${ }^{2}$ School of Economics and Management, University of Electronics Science and Technology, Chengdu, \\ China \\ *E-mail of the corresponding author: frankdanquahosei@gmail.com
}

\begin{abstract}
This study used both qualitative and quantitative methods to explore the unique motivational factors affecting teachers' performance among senior high school teachers in the Ghana education service within the Kumasi metropolis. The study employed purposive and simple random sampling techniques in the selection of the senior high schools in the Kumasi metropolis. The target teacher population used in this work was 310 out of which 166 participants was obtained. Data was collected using questionnaires as the main research instruments and analyzed by means of descriptive statistics, namely; frequencies and percentage. The research disclosed that the major cause of low performance of teachers at the senior high schools was as a result of low motivation. The analysis of the research sample identified unique performance factors such as: the absence of "praise" for work well done; the absence of public recognition; and job training and development. Based on the results computation of correlation, it was discovered that, there is a moderate relationship between motivational factors and teacher performance among senior high schools in the Kumasi metropolis, which had an $R$ value of 0.556 . The $R$ square value which is 0.309 indicate that there is a model fit. It was also established that; the overall fitness of the model is accepted. The researchers recommended that stakeholder in the education sector should study the three-unique motivational factors that have a great deal of impact of teacher performance and apply it in their school for high teacher output.
\end{abstract}

Keywords: Motivational Practices, Fringe Benefits, Nature of Working Conditions, Teachers Performance 
INTERNATIONAL JOURNAL OF ACADEMIC RESEARCH IN BUSINESS AND SOCIAL SCIENCES

Vol. 9, No. 2, Feb, 2019, E-ISSN: 222 2-6990 @ 2019 HRMARS

\section{Introduction}

In several nations, especially developing countries, civic services are given less resources meanwhile those departments encounter complex problems that progressively get difficult to solve. Academicians are of the view that public officers have an inherent motivation to work hard to accomplish any assigned duty. Working as a civil officer has been associated with "an attitude", a sense of "duty" and "public morality". However, these inherent motivations that used to be the main public service drive and the sense of self-worth amid public officials have been in dwindling for several years now. According to Justine, (2011) employees are the key resources in sustaining the institutions long term competitive advantage and the ability to attract, maintain, retain and motivate its workforce influence the sustainability of a constant success. Therefore, the researcher has observed that by considering the strategic comparison of the employees' motivation and their effect at the work place are very pertinent in any institution that seeks to achieve optimal performance.

Kemmerer (1990), views the term incentive as all the direct and indirect benefits offered to employees so as to stir intrinsic motivators. More especially, he states that direct monitory incentives and all other financial resources are needed to be offered to employees to urge them to give out their very best. These motivations might be professional support, such as; initial and continuing training programs, teacher guides, fringe benefits, free or partly sponsored housing, food and transportation or even allowances. On the other hand, motivation could be non-monetary such as high professional status in the community, promotions, recognition and endorsement by parents, public or the ministry. It is believed that, when a teacher is given motivation, his or her performance is influenced positively. Therefore, this study on motivational practices, pays much attention on fringe benefit and working condition. However, from the researcher's perception, it is a force within the individual that produces the behaviors focused towards a certain sequence of action. Motivation arises as a result of the interaction of individuals and the conditions that surrounds his or her work. Motivation and performance are thought to be directly related and by this research we delve into the entire concept of motivation and its relation to performance.

Organization's output is an important factor in every established institution or department. Whether an establishment is set up by governments or individuals, the objective is to serve the society and achieve gains in return and this objective is not different from government sponsored educational institutions. In Ghana, Public Service establishments such as Ghana Education Service personnel have the feeling that they are not being motivated well enough, as in inadequate salary and fringe benefits always constitutes the key factor for low motivation and performance.

The government of Ghana is therefore focused on implementing strategies of enhancing teachers' output, and some of the strategies includes increasing teachers' salaries and upgrading the status of the performing teachers. The researcher therefore, wants to further study if there are other factors that motivate teachers other than salary payments. In most schools, teachers are not satisfactorily motivated and even the working conditions are still not attractive, fringe benefits like allowances, recognitions, promotions and praises infrequently occur regardless of the commitment displayed by the workers. A large number of the teachers still work under strict supervisions and work over loaded without appointment letters (job security), hence, affecting their work. Unfortunately, in most African nations like Ghana, teaching is a relatively low paying profession compared to others like lawyers, accountants, engineers that require a similar standard of education in its practice and it is 
widely believed that recruitment to the teaching profession is adversely affected by low motivation, hence, a substantial number of suitable qualified students who would otherwise be motivated towards teaching are discouraged by; low salaries, inadequate allowances, inadequate fringe benefits and other forms of incentives.

The methods of rewarding employees differ from institution to institution, for various reasons and at particular situations. As anticipated, Ghanaian administrators still see employee motivation to be a matter of main concern due to the connection between motivation and performance. The seriousness of this issue for both administrators and other workers is linked, to poor organizational performance, individual frustration and alienation at work. Information gathered from the literature suggests that some of the variables affecting motivation and subsequent performance are: job satisfaction, leadership recognition for good and hard work, good working conditions, promotion etc Herzberg (1954). Most of these variables affecting motivation and subsequent performance will be found in the internal operations of the Ghana Education Service. In Ghana, the Government is responsible for the motivation of teachers so to make them enjoy their work and advance appropriate characters to come out with excellent professional practice needed for quality education in the country. However, a lot needs to be done to achieve this aim. In schools, most teachers and students are continually on the look out to gain fame, to be praised, to be promoted and even to gain physical rewards from their supervisor, parents, guardians, teachers and others. The contrary of this situation may mean little drive towards performance or even abandoning the activity. Therefore, establishments like schools cannot successfully achieve their task without motivating their staffs to work together for the accomplishment of the set goals. These motivations have a lot to do with teachers' motivational level, teacher's behaviors, teaching style, the structure of the course and informal interactions with learners all having a large impact. Similarly, teachers are required to be motivated in monetary and other incentives in order to be best performers in the work

Motivation is vital and makes teachers positive about their own learning, creating a drive in them to acquire their targets. By realizing their perfection and achievement, teachers continuously gain the sense of success. The researcher therefore, investigated if there are additional factors that motivate teachers other than payments. According to Herzberg (1954), most of the workers in institutions tend to trace the good results to their own efforts and shoulder the blame to the administration in case of poor results. Utmost performance cannot be obtained at its fullest in every organization but when authorities in various schools engage in power sharing and cooperation with no command over other subordinates but serving them, advising, directing, motivating and appreciating their efforts to meet the desired goals, higher performance would be ascertained.

Another challenging situation is absenteeism in the classrooms as it is on the increase these days. This particular issue has been attributed to lack of motivation and dissatisfaction among teachers for more than decades which compel them to leave for other works. In a draft report to examine teacher attrition in Ghana, a joint research by the Ghana National Association of Teachers (GNAT) and the Teachers and Educational Workers Union (TEWU) has revealed that about 10,000 teachers in public pre-tertiary schools in Ghana leave the classroom every year because majority of them thinks the recognition given to them by students, parents and the community and the government as a whole as compared to their colleagues in other professions is not the best. Another source (Ghana Web) has documented that, as high as 33,185 teachers in public pre - tertiary schools 
INTERNATIONAL JOURNAL OF ACADEMIC RESEARCH IN BUSINESS AND SOCIAL SCIENCES

Vol. 9, No. 2, Feb, 2019, E-ISSN: 222 2-6990 (C) 2019 HRMARS

in Ghana have vacated posts in recent years in search of greener pastures abroad or in other professions because of low pay, promotion issues and other unfavorable working conditions nonavailability of job training or development. Given the crucial role teachers play in Ghana's education development, the researcher thinks the above situation poses a significant threat to the country's effort at meeting its Education for All (EFA) goals by 2030. Therefore, the researchers feel that once all this equipment is provided adequately and in time, teachers would feel intrinsically happy and perform above average in schools.

\section{Objectives of the Study}

The objectives of this research are summarized as follows

i. To identify the unique factors that affect teacher performance in Ghana Education service in the Kumasi metropolis.

ii. To identify the relationship between motivational factors and teacher performance.

iii. To make recommendations about the ways to upgrade motivation and performance in Ghana Education service.

\section{Review of Related Literature}

\section{Content Theory}

The theories suggested by Maslow, Alderfer, Hertzberg and McClelland are content theories. Maslow argues that humans "want beings". They have inmates desire to satisfy a given set of needs. Maslow said, the needs are organized in a hierarchy of importance called prepotency. Higher level needs are not important and are not manifest until lower-level needs are satisfied (Maslow, 1943).

The content theories are characterized by emphasis on what motivates people or employees. They concern with individual's goals and needs which are said to be the same for every person. Although, they assume that all people possess a similar set of needs they differ in defining what those needs are. The most well-known and much cited author of motivation theory is Maslow with his hierarchy of human needs. In Maslow's point of view human behavior is driven by the existence of unsatisfied needs. His hierarchy starts from psychological needs and leads through security needs, social needs, self-esteem needs, and self-actualization needs on the top position.

According to Maslow, (1943), higher needs are not felt until lower needs are fulfilled. Additionally, when the need is satisfied it does not influence human behavior anymore and as a result the focus is shift onto a need which is higher in the hierarchy. Maslow divided needs into two categories: deficiency needs and high-order needs. Deficiency needs include basic needs such as hunger or thirst and a need for shelter and protection. When these needs are, satisfied people become motivated by high order needs such as the need for supportive and satisfactory relationships with others, needs for freedom, independence, recognition and achievement and finally the need to develop one's potential. The self-actualization which is the uppermost step in Maslow's pyramid can be described as the ending point of gradual psychological maturation process. This final level is attained by few people and unlike other needs is never fully satisfied. Maslow's work on the theory of needs has been followed by other authors who took an attempt to improve it. One of modifications was by Alderfer (Latham, \& Pinder, 2005)., who developed and tested model with fewer needs levels. His study, unlike Maslow's, was based on empirical research in organizational settings. The theory suggests three 
general categories of human needs which are partly based on Maslow's model but are not the same. Maslow differentiated between any certain transitions among the needs.

In the 1950's psychologist Frederick Herzberg (Maslow, 1943) proposed, a theory of motivation that focuses on the job and on the environment where work is done. Herzberg studied various factors relating to the job and their relation to employee motivation and concluded that they can be divided into hygiene factors and motivational factors. Hygiene factors, which relate to the work setting and not the content of the work, include adequate wages, comfortable and safe working conditions, fair company policies, and job security. These factors do not necessarily motivate employees to excel but will definitely have an effect on the employees' performance and their absence may be a potential source of employee dissatisfaction. Hertzberg said, hygiene factors do not motivate. The lack of hygiene factors at work would simply mean that employees are not motivated. Thus, an organization must be conceived with ensuring that both the hygiene factors and motivators are to an adequate standard. It is important to note that with Maslow, the satisfaction or a higher need leads to the next but with Hertzberg, they have two different status factors which are distinct from each other. Status is placed in between motivators and hygiene because when it is achieved, it becomes a motivator and when it is not achieved it becomes a hygiene factor. One major weakness of theories is that it makes no allowance for the different meanings which individuals attach to work or their orientations. Herzberg's theory brought a lot of interest from academics and from managers who were looking for ways of motivating their employees. The reason for so much interest in Herzberg's results comes from a dual character of his work. His theory not only describes employees' needs but also goes further and presents how to enrich jobs and make workforce more motivated. Herzberg indicates that job satisfaction and job dissatisfaction are not opposite phenomena. According to him the opposite of satisfaction is rather no satisfaction and the opposite of dissatisfaction is no dissatisfaction. Herzberg suggests that satisfaction and dissatisfaction are produced by different factors. People are satisfied at their work by factors related to content of that work. Those factors are called intrinsic motivators and contain achievement, recognition, interesting work, responsibility, advancement and growth. Factors that make people unhappy with their work are called dissatisfies or hygiene factors. Herzberg found the following as dissatisfies: company policy, supervision, working conditions, interpersonal relationships, salary, status, security. What makes them different from motivators is the fact that they are not related to the content of the work but to the context of the job.

Herzberg results were also attacked because he did not try to measure relationship between performance and satisfaction. As can be seen from this short overview of controversies and overlaps on content theories not every theory managed to defend itself during decades. However, most of them influenced the growth of interest in the topic of work motivation. In the next part of this paper more recently developed theories will be described and analyzed.

Although Herzberg's paradigm of hygiene and motivating factors and Maslow's hierarchy of needs may still have broad applicability in the business world, at least one aspect of each, salary as a hygiene factor (Herzberg) and esteem as a lower order need than self-actualization (Maslow), does not seem to hold in the case of elementary and senior high school teachers. These findings may begin to explain why good teachers are being lost to other, higher paying positions and to help administrators focus more closely on the esteem needs of teachers, individually and collectively. 


\section{Process Theory}

Process theories are characterized by a dynamic character, not static as content theories. The main concern is not what motivates people but how motivation occurs. Process theories try to explain how and why peoples' behavior is directed to certain choices. The focus of all process theories is put on the role of individual's cognitive processes in determining his or her level of motivation. The process theory which seems to be the core one is the Expectancy Theory. This model was originally presented by Vroom however, many other later researchers tried to adapt and develop it.

Latham, and Pinder, (2005)., theory is based on the belief that employee effort will lead to performance and performance will lead to rewards and rewards may be either positive or negative. The more positive the reward the more likely the employee will be highly motivated. Conversely, the more negative the reward the less likely the employee will be motivated. According Goodwin, and Horowitz, (2002), employee's behaviors that lead to positive outcomes which will be repeated and behaviors that lead to negative outcomes which will not be repeated. Therefore, managers should positively reinforce employee behaviors that lead to positive outcomes and negatively reinforce employee behavior that leads to negative outcomes.

According to Van Eerde, and Thierry, (1996) expectancy theory is the most comprehensive motivational model that seeks to predict or explain task-related effort. Vroom's Expectancy theory compromises three factors: valence, instrumentality and expectancy. Vroom describes valence in a relation to peoples' affecting preferences toward particular outcomes. The valence of outcome is positive if a person prefers attaining it instead of not attaining. Oppositely, the negative valence of outcomes characterize situation when a person prefers not attaining it instead of attaining. The third possibility is zero valence of outcome, which means that a person is indifferent between attaining outcome or not. The instrumentality is a belief that one action lead to another. Finally, the expectancy is defined as a belief about likelihood that a particular behavior will be followed by a particular outcome (Clegg, \& Bailey, 2007). Values of those three factors can be used to calculate the motivational force of the job, Summarizing, Vroom's theory suggests that a job is motivating for employees when they can see a relation between performance and outcome, if they have abilities to do the job and if they see outcome as satisfying their needs. Vroom's theory can be a suggestion for managers to focus on main aspects of their subordinate's perceptions.

\section{Hypothesis of the Study Recognition}

It is a useful positive tool where usually people get recognized by their work and job done and based on that they receive recognition. Güngör (2011) stated that employees work harder when they are recognized and appreciated for their effort toward the work given them. When employees get recognized and appreciated, they do their best to prove their skills, talents and abilities they have (Güngör, 2011). Furthermore, recognizing employees is also considered a way of communication that strengthens and rewards the outcomes people create. For that reason, leaders should develop recognition system which is powerful for both employees and organization (Lin, 2007). Employees who feel appreciated and recognized are more positive about themselves and their abilities to contribute. It also guarantees positive, productive and innovative organization environment. Saying thank you as recognition will make the business successful (Sirota \& Mischkind, 2006) 
INTERNATIONAL JOURNAL OF ACADEMIC RESEARCH IN BUSINESS AND SOCIAL SCIENCES

Vol. 9, No. 2, Feb, 2019, E-ISSN: 2222-6990 C 2019 HRMARS

$\mathrm{H} 1$ : There is a positive relationship between recognition as an independent variable and the dependent variable teacher performance.

\section{Praise for work well done}

This is one of the effective methods being used to motivate individuals. Saying thanks and admiring individuals is one of the most usually used ways of motivating employees. It is stress-free to use, and it is said usually from the heart and naturally. Looking in the employee's eyes in front of others and say thanks, really means a lot. Employees appreciate being recognized for doing a great job and the feeling of being valued as an individual. The praise tends to carry even greater meaning and motivational effect. Greig, (1984) stated that praise was the response of the most of employees who surveyed about motivation (Greig, 1984). Also, attendees from different seminars about motivation agreed that praise is the most important thing when motivating employees. When it comes to getting the best performance from employees, praise should be on the top of the motivation approaches list. When employees feel that their managers appreciate and praise them, they tend to perform better which leads to higher business productivity (Hamjah et al., 2011). So, the more managers' praise their employees, the easier the tasks will be and the more productive they will be. Based on this a hypothesis was developed as;

$\mathrm{H} 2$ : There is a positive relationship between praise for work well done as an independent variable and the dependent variable teacher performance.

\section{Training and Development}

"Training" refers to a systematic approach to learning and development to improve individual, team, and organizational effectiveness. Alternatively, development refers to activities leading to the acquisition of new knowledge or skills for purposes of personal growth (Goldstein, \& Ford, 2002). However, it is often difficult to ascertain whether a specific research study addresses training, development, or both. Gazioglu, \& Tansel, (2006), in their work found a significant positive relation of training and job satisfaction in Britain using ordered Probit estimation. Based on these discussions the following hypothesis is proposed:

$\mathrm{H} 3$ : There is a relationship between training and development as an independent variable and the dependent variable teacher performance. 
INTERNATIONAL JOURNAL OF ACADEMIC RESEARCH IN BUSINESS AND SOCIAL SCIENCES

Vol. 9, No. 2, Feb, 2019, E-ISSN: 2222-6990 C 2019 HRMARS

\section{Conceptual Framework}

The motivation practice includes provision of fringe benefits and adequate good working conditions are the independent variables while the teacher's performance is the dependent variable.

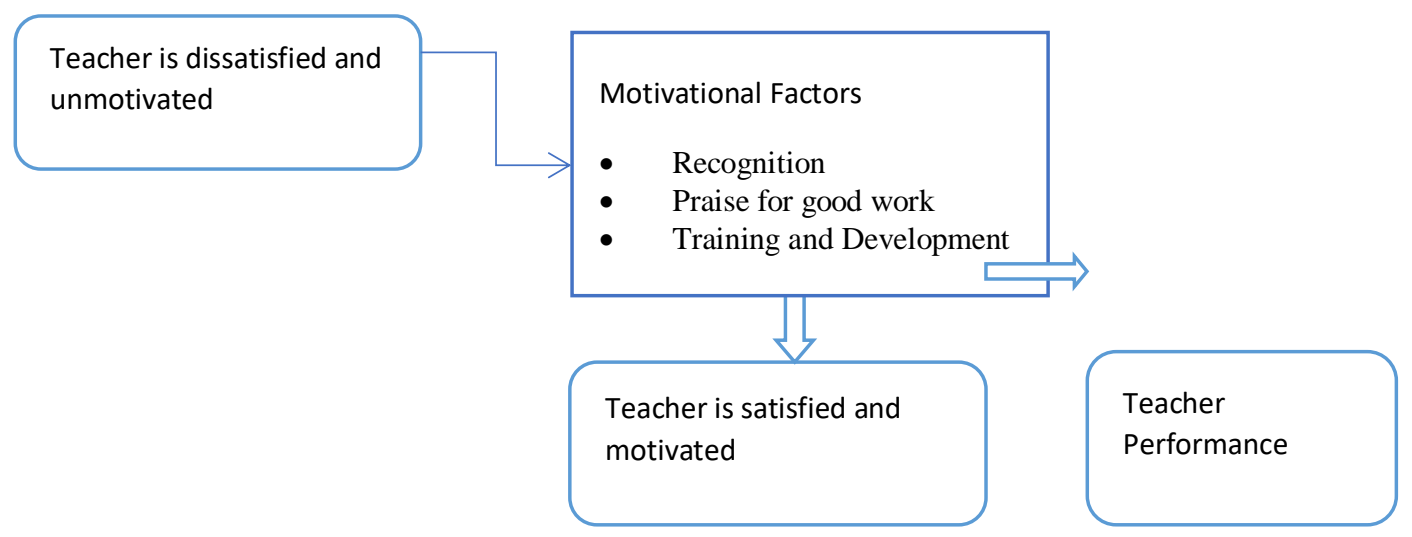

Figure 2-2 Source: Researcher's Construct, 2017

Normally, teachers feel dissatisfied and unmotivated in their schools but with the introduction of the motivational factors it makes them satisfied and motivated and later how does it affect their performance is what the figure depicts. The figure above presents the relationship between motivational practices and teachers performance. It basically tackles the provision of non-monetary incentives for the teacher's effective performance. In well-motivated schools, teachers are more willing to enhance their teaching skills, exert efforts in the school's activities, as reflected in their participation and commitment where monetary incentives like salaries and wages are paid to the teaching staff; these have great impact on workers' performance in institutions. The provision of motivational factors provides more morale to the workers to remain committed to the organization's set goals hence, job satisfaction which leads to an increase in participation in the institution's activities for better performance.

\section{Study Methodology}

Research Design and Sampling Technique

The study design embraced for the investigation was a descriptive survey. This plan is viewed as proper on the grounds that it empowers the study to produce information through the institutionalized gathering techniques in light of very organized research instrument(s) and welldefined study ideas and related factors. Conclusively, descriptive research was embraced on the grounds that its point is to accomplish the accompanying objectives: give an exact profile of a gathering or circumstance; offer depiction to a process, instrument or relationship; give a verbal or numerical picture of the circumstance; source for data to animate new clarifications; contextual presentation of basic background information; and categorization of the problems and documentation of information that contradicts prior beliefs about a subject. A comprehensive questionnaire designed to cover the objectives of the study was used to collect the data. 
INTERNATIONAL JOURNAL OF ACADEMIC RESEARCH IN BUSINESS AND SOCIAL SCIENCES

Vol. 9, No. 2, Feb, 2019, E-ISSN: 2222-6990 C 2019 HRMARS

\section{Population and Sample Size}

According to Saunders et al (2009) the target group about which the researcher is interested in gaining information and drawing conclusions is what is known as the population. The population in this research covered all Senior High School teaching staff of Ghana Education Service in the Kumasi Metropolis totaling about 310. In this study, the Sample Frame consists of workers who are currently employed Ghana Education Service and specifically Kumasi Metropolis. Out of a population of 310 personnel, data was collected from a sample size of 166 respondents. The sample represents $54 \%$ of the population. The sample size was determined by the scope of the research, which is limited in nature. It was also based on the budget and ease of accessibility of the respondents from within the researcher's work sector.

\section{Data Analysis Method}

Both qualitative and quantitative measurers were used for the data analysis. Quantitatively, result from the structured questionnaire was analyzed using excel and statistical Package for Social Scientist (SPSS). All primary data sets were subjected to tabular and statistical analysis involving simple and easy to understand statistical measures like frequency and percentage chart. As per the objective of the research graphs tables. The qualitative measures dealt with the assessment of perception of the workers interviewed and their reaction towards the effects of motivation on performance. The multiple regression model is specified as follows:

$$
T P=\beta_{0}+\beta_{1} R+\beta_{2} P+\beta_{3} T D+\mathrm{e}
$$

Where $\beta_{0}=$ Measures teachers' performance holding all the independent variables constant.

$\beta_{1}, \beta_{2}, \beta_{3}=$ are the coefficient of the independent variables (Recognition, Praise and Training and Development.)

$\mathrm{e}=$ error term.

$\mathrm{R}=$ Recognition.

$P=$ Praise for work well done.

$\mathrm{T}=$ Training and Development. 
INTERNATIONAL JOURNAL OF ACADEMIC RESEARCH IN BUSINESS AND SOCIAL SCIENCES

Vol. 9, No. 2, Feb, 2019, E-ISSN: 2222-6990 C 2019 HRMARS

\section{Empirical Results and Discussions}

Socio-Economic Demographic Characteristics of Respondent's

The socio-economic demographic characteristics of the respondents are summarized in Table 1.

Table 1: Socio-economic Demographic Characteristics of Respondents

\begin{tabular}{|c|c|c|c|}
\hline & & $\mathrm{N}$ & $\%$ \\
\hline \multirow[t]{3}{*}{ Gender } & Female & 63 & 38 \\
\hline & Male & 103 & 62 \\
\hline & Total & 166 & 100 \\
\hline \multirow{7}{*}{ Age group } & Below 20 years & 4 & 2 \\
\hline & $21-30$ years & 30 & 18 \\
\hline & $31-40$ years & 78 & 47 \\
\hline & $41-50$ years & 40 & 24 \\
\hline & $51-60$ years & 13 & 8 \\
\hline & 45 and above & 1 & 1 \\
\hline & Total & 116 & 100 \\
\hline \multirow[t]{4}{*}{ Education } & Diploma/Certificate A & 56 & 34 \\
\hline & Bachelor's Degree & 84 & 51 \\
\hline & Masters & 26 & 15 \\
\hline & Total & 116 & 100 \\
\hline \multirow{5}{*}{ Working Experience } & $0-4$ years & 76 & 46 \\
\hline & $5-10$ years & 71 & 43 \\
\hline & $11-15$ years & 10 & 6 \\
\hline & Over 16 years & 9 & 5 \\
\hline & Total & 116 & 100.0 \\
\hline \multirow{6}{*}{ Grade/Level } & Senior Superintendent II & 39 & 23 \\
\hline & Senior Superintendent I & 26 & 16 \\
\hline & Principal Superintendent & 64 & 39 \\
\hline & Assistant Director I & 28 & 17 \\
\hline & Assistant Director and above & 9 & 5 \\
\hline & Total & 116 & 100.0 \\
\hline
\end{tabular}

\section{Source: Researcher's Field Data, 2017}

Out of the sample reviewed (166), 103 teachers representing 62\% are male while 63 teachers representing 38\% are female. Records from the Ghana education service sector shows that there are more male teachers than females. This could be attributed to the nature of the services hence more men were taken than women.

From the table above, teachers between the ages of 31-39 recorded the highest frequency of 78 people having a percentage of $47 \%$, second to them was those between the ages of $41-50$ years with a frequency of 40 people having a percentage of $24 \%$. Teachers between the ages of $21-30$ recorded 30 people with a percentage of $18 \%$. The next was teachers between the ages $51-60$ years. There 
were 13 people having a percentage of $18 \%$. There was 4 people under the age of 21 . This record depicts the youthful nature of teachers in Kumasi metropolis and in large Ghana Education Service.

The table above further portrays that teachers with Bachelor's Degree are the majority in the senior high school level of Ghana's education system recording a percentage of $51 \%$ with a frequency of 84 teachers. Second to this category was teachers with Diploma/Certificate " $A$ " also recording $34 \%$ and a frequency of 56 teachers. Teachers with Master's Degree were 26 in terms of frequency and 15 in terms of percentage.

From the responses, 76 teachers representing 46\% were in their early stages of teaching that is within four years of working. The number reduced to 71 teachers representing $43 \%$ for teacher who have work with 5-10 years. A number of 10 teachers representing $6 \%$ said they have worked for 11 15 years as teachers, which depict another reduction. The least was teachers who have worked over 16 years they were 9 with a percentage of $5 \%$.

Ghana educations service have levels and structures that teachers must attain. The level or grade is gained through long service and education attainments. From the table above, only 9 persons representing $5 \%$ was having the grade of Assistant Director. The study discovered that teachers with that high level or grade normally move to work in the offices than to stay in the classroom to teach. Following are the teachers with the grade level of Assistant Director I, they were 28 teachers representing a percentage of $17 \%$. A number of 39 teachers were with the grade level of Senior Superintendent II which is $23 \%$ of the total respondents. 26 of another group of teachers was Senior Superintendent I with a percentage of $16 \%$. The highest was teachers that are Principal Superintendent, they recorded 64 teachers with a percentage of $39 \%$. 
INTERNATIONAL JOURNAL OF ACADEMIC RESEARCH IN BUSINESS AND SOCIAL SCIENCES

Vol. 9, No. 2, Feb, 2019, E-ISSN: 2222-6990 C 2019 HRMARS

\section{Summary of Financial Rewards}

From the table below, it came to light that 6 of the financial rewards were not selected by the respondents which represents $40 \%$ of the total options of financial rewards presented to the respondents. This was because those rewards are not applicable their organizations or schools. The selected financial rewards were 9 with a percentage of $60 \%$. Three of the rewards recorded $100 \%$ as all respondents selected it, they were, (Basic Salary, Retirement Benefits, and Paid Vacations). The remaining financial rewards recorded a percentage ranging from $23 \%-50 \%$.

Table 2 Financial Rewards

\begin{tabular}{|l|l|l|l|}
\hline \multirow{5}{*}{ Membership Rewards } & Reward & Frequency & Percentage \\
\cline { 2 - 4 } & Basic Salary & 166 & 100 \\
\cline { 2 - 4 } & Retirement Benefits & 166 & 100 \\
\cline { 2 - 4 } & Car Allowance & 45 & 27 \\
\cline { 2 - 4 } & Medical Aids & 83 & 50 \\
\cline { 2 - 4 } & Subsidized Canteen & 39 & 23 \\
\cline { 2 - 4 } & Pay Vacation & 166 & 100 \\
\cline { 2 - 4 } & Profit Sharing & 0 & 0 \\
\cline { 2 - 4 } & Thirteenth Cheque & 0 & 0 \\
\hline \multirow{5}{*}{ Performance Rewards } & Commission Pay & 0 & 0 \\
\cline { 2 - 4 } & Share Option & 0 & 0 \\
\cline { 2 - 4 } & Stock Ownership & 0 & 0 \\
\cline { 2 - 4 } & Performance Bonuses & 71 & 43 \\
\cline { 2 - 4 } & Merit pay & 0 & 0 \\
\cline { 2 - 4 } & Incentive scheme & 43 & 26 \\
\cline { 2 - 4 } & Achievement Awards & 75 & 45 \\
\hline
\end{tabular}

\section{Source: Researcher's Field Data, 2017}

\section{Summary of Non-Financial Rewards}

The non-financial rewards that focus more on perceptions and the social communication aspect of working received low rating of selection. With an exception of friendly greeting. McClelland descried these rewards in Armstrong, (2006) as "Affiliation motivational needs" where people strive for friendly associations, interactions and friendship with others. On the issue of non-financial reward there was a great percentage of non-selection. It was noticed that 9 non-financial rewards were not selected representing $67 \%$ of the total of 15 non-financial rewards. Even with the selected once with the exception of friendly greetings and personal growth opportunities, the remaining ones recorded percentages between $20 \%-25 \%$. Personal growth opportunities recorded $57 \%$. The highest recorded reward at this aspect of non-financial was friendly greetings. The researcher found that that there was high percentage because according to Murlis (2004) these rewards are known as "affiliation motivational needs" where people strive for friendly associations, interactions and friendships with others. The researcher found out that there is a great problem when it comes to non-financial rewards as compared to the number of selections in the financial rewards. 
INTERNATIONAL JOURNAL OF ACADEMIC RESEARCH IN BUSINESS AND SOCIAL SCIENCES Vol. 9, No. 2, Feb, 2019, E-ISSN: 2222-6990 C 2019 HRMARS

Table 3 Financial Rewards

\begin{tabular}{|c|c|c|c|}
\hline \multirow{7}{*}{ Status Rewards } & Rewards & Frequency & Percentage \\
\hline & Choice in office location & 0 & 0 \\
\hline & Choice in furnishing & 0 & 0 \\
\hline & Personal assigned parking & 0 & 0 \\
\hline & Own secretary & 0 & 0 \\
\hline & Public recognition & 0 & 0 \\
\hline & $\begin{array}{l}\text { Convenience service eg Gym, room, } \\
\text { Canteen }\end{array}$ & 0 & 0 \\
\hline \multirow{5}{*}{ Social Rewards } & Praise for work well done & 41 & 25 \\
\hline & Compliment for achievement & 33 & 20 \\
\hline & Friendly greetings & 137 & 83 \\
\hline & Non-official dinner invitation & 0 & 0 \\
\hline & Work social gathering & 0 & 0 \\
\hline \multirow{4}{*}{ Intrinsic Rewards } & $\begin{array}{ll}\text { Increasing } & \text { responsibility/ } \\
\text { promotion } & \\
\end{array}$ & 0 & 0 \\
\hline & Personal growth opportunities & 94 & 57 \\
\hline & More interesting work & 41 & 25 \\
\hline & Autonomy & 0 & 0 \\
\hline
\end{tabular}

Source: Researcher's Field Data, 2017

\section{Motivational Factors and Teachers Performance}

With reference to the Table 4 below, a summary of the frequency and percentage of respondents is presented. The issue of recognition as a motivational factor saw a high percentage of respondents strongly agreeing and agree to the statement. The number of respondents who were neutral of the three statements of recognition was almost the same as the number of respondents who strongly disagree and disagree to the statement. On the question of praise for work well done the greater number of respondents strongly agree and agree to the accession that they are been praise for their work. Those who strongly disagree and disagree were the least. Training and Development also recorded a great number of respondents strongly agreeing and agreeing to the statement. Those who strongly disagree and disagree were the least as compared to those who were neutral.

Teachers were asked about how the motivational factors affect or influence their performance in terms of student's report, exams setting time and scheme of work. It was realized that, there was a higher frequency for all the three statements, that is majority of the respondents strongly agree and agree to the statements about performance. Respondents who remained neutral were a little higher than those who strongly disagree and disagree to the statements to the extent that the statement on student's report recorded zero on strongly disagree.

Table 4 Motivational Factors and Performance. 
INTERNATIONAL JOURNAL OF ACADEMIC RESEARCH IN BUSINESS AND SOCIAL SCIENCES

Vol. 9, No. 2, Feb, 2019, E-ISSN: 2222-6990 @ 2019 HRMARS

\begin{tabular}{|c|c|c|c|c|c|c|c|c|c|c|c|}
\hline \multirow[t]{2}{*}{ Variables } & \multirow[t]{2}{*}{ Items } & \multicolumn{2}{|c|}{$\begin{array}{l}\text { Strongly } \\
\text { Disagree }\end{array}$} & \multicolumn{2}{|c|}{ Disagree } & \multicolumn{2}{|c|}{ Neutral } & \multicolumn{2}{|c|}{ Agree } & \multicolumn{2}{|c|}{$\begin{array}{l}\text { Strongly } \\
\text { Agree }\end{array}$} \\
\hline & & $\mathrm{F}$ & $\%$ & $\mathrm{~F}$ & $\%$ & $\mathrm{~F}$ & $\%$ & $\mathrm{~F}$ & $\%$ & $\mathrm{~F}$ & $\%$ \\
\hline \multirow{3}{*}{ Recognition } & $\begin{array}{l}\text { Recognition at work } \\
\text { place improve teachers } \\
\text { moral and commitment }\end{array}$ & 6 & 4 & 8 & 5 & 19 & 11 & 60 & 36 & 73 & 44 \\
\hline & $\begin{array}{l}\text { The school } \\
\text { administrators make } \\
\text { sure that teachers are } \\
\text { recognized for their work } \\
\text { well done }\end{array}$ & 6 & 4 & 8 & 5 & 19 & 11 & 73 & 44 & 60 & 36 \\
\hline & $\begin{array}{l}\text { Promotion is the one of } \\
\text { the factors that the } \\
\text { administrators does not } \\
\text { take for granted }\end{array}$ & 9 & 5 & 15 & 9 & 12 & 7 & 29 & 17 & 101 & 61 \\
\hline Praise & $\begin{array}{l}\text { There is always occasion } \\
\text { teachers are praised for } \\
\text { work well done }\end{array}$ & 6 & 4 & 8 & 5 & 19 & 11 & 60 & 36 & 73 & 44 \\
\hline \multirow{2}{*}{$\begin{array}{l}\text { Training and } \\
\text { Development }\end{array}$} & $\begin{array}{l}\text { Work based training and } \\
\text { development affect my } \\
\text { performance. }\end{array}$ & 5 & 3 & 7 & 4 & 8 & 5 & 24 & 14 & 122 & 73 \\
\hline & $\begin{array}{l}\text { I have benefitted from } \\
\text { training and } \\
\text { development for the } \\
\text { past } 12 \text { months }\end{array}$ & 2 & 1 & 15 & 9 & 19 & 11 & 78 & 47 & 52 & 31 \\
\hline \multirow{3}{*}{$\begin{array}{l}\text { Teacher } \\
\text { Performance }\end{array}$} & $\begin{array}{l}\text { Motivational factors } \\
\text { affect my performance in } \\
\text { term of exam setting } \\
\text { time. }\end{array}$ & 8 & 5 & 6 & 4 & 19 & 11 & 60 & 36 & 73 & 44 \\
\hline & $\begin{array}{l}\text { Motivational factor } \\
\text { affects my performance } \\
\text { in terms of scheme of } \\
\text { work. }\end{array}$ & 10 & 6 & 2 & 1 & 16 & 10 & 58 & 35 & 80 & 48 \\
\hline & $\begin{array}{l}\text { Motivational factors } \\
\text { influence my } \\
\text { performance in terms of } \\
\text { student report. }\end{array}$ & 0 & 0 & 2 & 1 & 13 & 8 & 64 & 39 & 87 & 52 \\
\hline
\end{tabular}

Source: Researcher's Field Data, 2017 
INTERNATIONAL JOURNAL OF ACADEMIC RESEARCH IN BUSINESS AND SOCIAL SCIENCES

Vol. 9, No. 2, Feb, 2019, E-ISSN: $2222-6990$ ๑ 2019 HRMARS

\section{Multiple Regression Results and Analysis}

On the account of the study to establish the relationship between motivational factors and teachers' performance among senior high schools in Kumasi metropolis, the table below depicts the relationship between these two factors.

Table 5 Multiple Regression Results

\begin{tabular}{|l|l|l|l|l|l|l|}
\hline \multirow{3}{*}{ Variables } & & coefficient & Std. Err. & $\mathrm{t}$ & $\mathrm{P}>\mathrm{t}$ & Beta \\
\cline { 2 - 7 } & Recognition & 0.312 & 0.073 & 4.303 & 0.000 & 0.466 \\
\cline { 2 - 7 } & Praise & 0.143 & 0.066 & 2.180 & 0.031 & 0.233 \\
\hline \multirow{3}{*}{} & Training and development & -0.003 & 0.054 & -0.054 & 0.957 & - \\
& & & & & & 0.004 \\
\hline Gender & Female & 0.177 & 0.143 & 1.236 & 0.218 & 0.153 \\
\hline $\begin{array}{l}\text { Service } \\
\text { Duration }\end{array}$ & Long Service & 0.487 & 0.119 & -4.086 & 0.000 & - \\
\cline { 2 - 7 } & Short Service & & & & & 0.343 \\
\hline
\end{tabular}

R-square $=0.402$, Adj. R- square $=0.379, \mathrm{~F}=17.780$.

Predictors (Constant), Recognition, Praise, Training and development.

The table above shows the regression analysis run with the controlled variables. After the multiple regression was run it was found out that, Recognition has a positive relationship with the dependent variable (teachers' performance) with a value of 0.312. It also has a significant impact on teachers' performance with a $p$ value of $0.000<0.05$. Praise as an independent variable also had a positive relationship (0.143) with teachers' performance and a significant impact with $p$ value 0.031 $<0.05$. On the other hand, training and development had a negative relationship (-0.003) with teachers' performance and did not have any significant impact on teacher performance with $p$ value of $0.957<0.05$. With regards to the controlled variables, Female was selected and male was used as the reference. It was found that Female has a positive relationship (0.177) with teachers' performance. That is there is an increase of 0.177 female as compared to male in connection of teachers' performance.

On service duration, medium service was used as the reference, both short service and long service had a positive relationship (0.171 and 0.487 ) respectively. This implies that, there will be an increase of 0.171 teachers in the short service as compared to medium service in connection with teachers' performance. Also, there will be an increase of 0.487 teachers' in the long service as compared to medium service. Both female and short service had an insignificant impact on the dependent variable with $p$ value of $0.218>0.05$ and $0.170>0.05$ respectively. On the other side, long service had a significant impact on the dependent variable $(0.000<0.05)$. The $R$ square value in the model $(0.402)$ which indicated $40.2 \%$ of the total variability in the dependent variable is predicted by the independent variables. The Adjusted R square value (0.379) which also indicate $37.9 \%$ of the changes in teachers' performance be explained by the model, however, about 62.1 of the variability cannot be explained by this model. The F statistics shows 17.780 which indicate that, the model has some explanatory power in the dependent variable.

\section{Discussion}

The purpose of this study was to find out the unique motivational factors and it impact on 
teachers' performance of training as well as suggest some measures in order to improve on the motivational needs of teacher in Kumasi metropolis and Ghana as a whole. Reliability analysis revealed that the scales used were internally consistent. Also, inter-correlations analysis confirms the validity of the dimensions of the scales. Collinearity diagnosis was run to ensure that there are no significant instances of multicollinearity.

On training and development against teachers' performance, the result shows that training and development could not significantly predict the dependent variable which is teachers' performance and also have a negative relationship. This disagrees with Caitlin (2002) who found that being satisfied with training was a significant predictor of job satisfaction and hence improve performance. The results also in contrast with $\mathrm{N}$ Tahir et al who did a study on training and development and employee job performance. They obtain a $p$ value of 0.000 which is $<0.05$ thus their model of the research is statistically significant (Tahir, et al., 2014). Therefore, the hypothesis can't be accepted. It must be stated that the independent variable (training and development) has no relationship with teachers' performance. Recognition and praise for good work done unlike training and development was able to significantly predict the dependent variable which is teacher performance and also has a positive relationship with it. The results are consistent with the study of Herzberg whose surveyed workers and divided work factors into two categories; Motivation factors, those factors that are strong contributors to job satisfaction. Motivating factors (challenging work, recognition, responsibility) that give positive satisfaction Hygiene factors, those factors that are not strong contributors to satisfaction but must be present to meet workers' expectations and prevent job dissatisfaction. The positive relationship and a strong significant impact of recognition on teacher performance is an indicator of how is unique in the field of education. With this result, the hypothesis cannot be rejected. Correlation analysis confirmed this hypothesis by establishing a significantly positive correlation between the level of participation in decision-making and the level of job satisfaction. The findings on this hypothesis concurred with Vandenabeele, (2007).

In a summery, this chapter presented the descriptive statistics and the results of the hypothesis testing together with the discussion of the study's findings. The results showed that training and development had a negative relationship with the dependent variable and it was insignificant in terms of impact. The results further indicated that, both recognition and praise had a relationship with the dependent variable and it was significant. Only one hypothesis was rejected. Lastly, overall the dependent variable was significantly predicted by one independent variables. The results were supported and discussed based on prior research findings.

\section{Conclusion and Recommendation}

In conclusion, the study affirmed that, the motivational factors that influence performance of teachers in Ghana are recognition, praise, training and performance appraisal. This conclusion is based on the general assertion of the teachers surveyed. The study again concluded based on the multiple regression estimation that Praise had a positive relationship with teachers' performance with a significant impact of 0.031 . The hypothesis was accepted under praise. The concluded that, good performance may not always be rewarded for high performing employees using traditional "rewards" such as appointment, promotion monetary. The management of the education sector may need to explore context appropriate rewards that comply with internal organizational guidelines but also to a 
large extent create a mutually beneficial performance relationship between both the management and the teachers.

Recognition has a positive relationship with the dependent variable (teachers' performance) with a value of 0.312 and it also has a significant impact on teachers' performance with a $p$ value of 0.000 $<0.05$ which makes the hypothesis accepted. The researchers concluded that, the absence of public recognition also has negative effect on the performance of teachers since they compare the respect, they gain from the public to that of other professions like Doctors, Nurses, Lawyers, Politician etc. of which they think they made all this profession so. The study further concluded that the absence of public recognition was one of the de motivators to most teachers in the senior high school level, and this may be a contributing factor of teacher switching to other professions like nursing, doctor, legal practitioners. On the other hand, training and development had a negative relationship (-0.003) with teachers' performance and did not have any significant impact on teacher performance with $p$ value of $0.957<0.05$ this makes the hypothesis to be rejected.

The study based on the findings recommended that administrators and government should always commend teachers for work well done to encourage them repeat such action often and also provide flexible working atmosphere to teachers to enable them balance work and leisure. Teachers who upgrade themselves individually must also be commended and their certificates gained must be accepted by the administrators.

Proprietors must make all teachers feel good and easy at the work place by paying these fringe benefits if performance is to be sustained. The head teachers should generate good teacher relationship and interact with their workforce easily and also recognize teachers' good performance in order to motivate others. They should also negotiate with the education offices to provide training for their teachers.

Finally, there is the need to compare the nature of working conditions in government aided senior high schools with those in other private senior high schools of similar status, in the same area and nationwide encouragements to their staff regularly.

\section{References}

Armstrong, M. (2006). Strategic Human Resource Management-A Guide to Action, 3rd Ed, Sage Publications.

Clegg, S., \& Bailey, J. R. (Eds.). (2007). International encyclopedia of organization studies. Sage Publications.

Kemmerer, F. (1990). The quality of education: a global perspective .Greenwood Press, New York, 135-152

Gazioglu, S., \& Tansel, A. (2006). Job satisfaction in Britain: individual and job-related factors. Applied economics, 38(10), 1163-1171.

Goldstein, I. L., \& Ford, J. K. (2002). Training in organizations: Needs assessment, development, and evaluation. Wadsworth/Thomson Learning.

Goodwin, J., \& Horowitz, R. (2002). Introduction: The methodological strengths and dilemmas of qualitative sociology. Qualitative Sociology, 25(1), 33-47.

Greig, I. (1984). Basic motivation and decision style in organization management. Omega, 12(1), 3141 
INTERNATIONAL JOURNAL OF ACADEMIC RESEARCH IN BUSINESS AND SOCIAL SCIENCES

Vol. 9, No. 2, Feb, 2019, E-ISSN: 2222-6990 C 2019 HRMARS

Güngör, P. (2011). The relationship between reward management system and employee performance with the mediating role of motivation: A quantitative study on global banks. Procedia-Social and Behavioral Sciences, 24, 1510-1520.

Murlis, H. (2004) Managing rewards [J] People Management: Challenges and Opportunities, Chapter 8.

Hamjah, S. H., Ismail, Z., Rasit, R. M., \& Rozali, E. A. (2011). Methods of increasing learning motivation among students. Procedia-Social and Behavioral Sciences, 18, 138-147.

Justine, N. (2011). Motivational Practices and Teachers' Performance in Jinja Municipality Secondary Schools, Jinja District, Uganda. Online Submission.

Latham, G. P., \& Pinder, C. C. (2005). Work motivation theory and research at the dawn of the twentyfirst century. Annu. Rev. Psychol., 56, 485-516.

Lin, H. F. (2007). Effects of extrinsic and intrinsic motivation on employee knowledge sharing intentions. Journal of information science, 33(2), 135-149.

Maslow, A. H. (1943). A theory of human motivation. Psychological review, 50(4), 370.

Osei, G. M. (2006). Teachers in Ghana: Issues of training, remuneration and effectiveness. International Journal of Educational Development, 26(1), 38-51.

Saunders, M., Lewis, P., \& Thornhill, A. (2009). Research methods for business students. Pearson education.

Tahir, N., Yousafzai, I. K., Jan, S., \& Hashim, M. (2014). The Impact of Training and Development on Employees Performance and Productivity A case study of United Bank Limited Peshawar City, KPK, Pakistan. International Journal of Academic Research in Business and Social Sciences, 4(4), 86.

Vandenabeele, W. (2007). Toward a public administration theory of public service motivation: An institutional approach. Public management review, 9(4), 545-556

Van Eerde, W., \& Thierry, H. (1996). Vroom's expectancy models and work-related criteria: A metaanalysis. Journal of applied psychology, 81(5), 575. 